\title{
Correction to: High diagnostic performance of independent alpha-synuclein seed amplification assays for detection of early Parkinson's disease
}

\author{
Marco J. Russo ${ }^{1 \dagger} \odot$, Christina D. Orru ${ }^{2 \dagger}$, Luis Concha-Marambio ${ }^{3{ }^{* \dagger}}$, Simone Giaisi ${ }^{4 \dagger}$, Bradley R. Groveman ${ }^{2}$, \\ Carly M. Farris ${ }^{3}$, Bret Holguin ${ }^{3}$, Andrew G. Hughson ${ }^{2}$, David-Erick LaFontant ${ }^{5}$, Chelsea Caspell-Garcia ${ }^{5}$, \\ Christopher S. Cofey ${ }^{5}$, Jennifer Mollon ${ }^{4}$, Samantha J. Hutten ${ }^{6}$, Kalpana Merchant ${ }^{7}$, Roland G. Heym ${ }^{4^{*}}$, \\ Claudio Soto ${ }^{3,8^{*}}$, Byron Caughey ${ }^{2^{*}}$ and Un Jung Kang ${ }^{1^{*}}$
}

\section{Correction to: acta neuropathol commun (2021) 9:179 https://doi.org/10.1186/s40478-021-01282-8}

During the publication process of the original article [1] an error was made and several corresponding authors were not shown.

The incorrect corresponding author was:

- Un Jung Kang

The correct corresponding authors are:

- Luis Concha-Marambio, Roland G. Heym, Claudio Soto, Byron Caughey and Un Jung Kang

The original article can be found online at https://doi.org/10.1186/s40478021-01282-8.

*Correspondence: luis@amprionme.com; roland.heym@abbvie.com; claudio. soto@uth.tmc.edu; bcaughey@nih.gov; un.kang@nyulangone.org

${ }^{\dagger}$ Marco J. Russo, Christina D. Orru, Luis Concha-Marambio and Simone

Giaisi have contributed equally to this work

${ }^{1}$ The Marlene and Paolo Fresco Institute for Parkinson's \& Movement Disorders, Department of Neurology, Department of Neuroscience and Physiology, Neuroscience Institute, The Parekh Center

for Interdisciplinary Neurology, NYU Grossman School of Medicine, New York, NY, USA

${ }^{2}$ Laboratory of Persistent Viral Diseases, Rocky Mountain Laboratories,

National Institute of Allergy and Infectious Diseases, National Institutes of Health, Hamilton, MT, USA

${ }^{3}$ R\&D Unit, Amprion Inc., San Diego, CA, USA

${ }^{4}$ AbbVie Deutschland GmbH \& Co. KG, Ludwigshafen, Germany

Full list of author information is available at the end of the article
The publisher apologizes for the inconvenience caused to the authors and readers.

\begin{abstract}
Author details
${ }^{1}$ The Marlene and Paolo Fresco Institute for Parkinson's \& Movement Disorders, Department of Neurology, Department of Neuroscience and Physiology, Neuroscience Institute, The Parekh Center for Interdisciplinary Neurology, NYU Grossman School of Medicine, New York, NY, USA. ${ }^{2}$ Laboratory of Persistent Viral Diseases, Rocky Mountain Laboratories, National Institute of Allergy and Infectious Diseases, National Institutes of Health, Hamilton, MT, USA. ${ }^{3}$ R\&D Unit, Amprion Inc., San Diego, CA, USA. ${ }^{4}$ AbbVie Deutschland GmbH \& Co. KG, Ludwigshafen, Germany. ${ }^{5}$ Department of Biostatistics, College of Public Health, University of lowa, lowa City, IA, USA. ${ }^{6}$ Michael J. Fox Foundation for Parkinson's Research, New York, NY, USA. ${ }^{7}$ Northwestern University Feinberg School of Medicine, Chicago, IL, USA. ${ }^{8}$ Mitchell Center for Alzheimer's Disease and Related Brain Disorders, Department of Neurology, University of Texas Houston Medical School, Houston, TX, USA.
\end{abstract}

Published online: 26 November 2021

\section{Reference}

1. Russo MJ, Orru CD, Concha-Marambio L et al (2021) High diagnostic performance of independent alpha-synuclein seed amplification assays for detection of early Parkinson's disease. Acta Neuropathol Commun 9:179. https://doi.org/10.1186/s40478-021-01282-8

\section{Publisher's Note}

Springer Nature remains neutral with regard to jurisdictional claims in published maps and institutional affiliations.

\section{$\triangle B M C$}

(c) The Author(s) 2021. Open Access This article is licensed under a Creative Commons Attribution 4.0 International License, which permits use, sharing, adaptation, distribution and reproduction in any medium or format, as long as you give appropriate credit to the original author(s) and the source, provide a link to the Creative Commons licence, and indicate if changes were made. The images or other third party material in this article are included in the article's Creative Commons licence, unless indicated otherwise in a credit line to the material. If material is not included in the article's Creative Commons licence and your intended use is not permitted by statutory regulation or exceeds the permitted use, you will need to obtain permission directly from the copyright holder. To view a copy of this licence, visit http://creativecommons.org/licenses/by/4.0/. The Creative Commons Public Domain Dedication waiver (http://creativecommons.org/publicdomain/zero/1.0/) applies to the data made available in this article, unless otherwise stated in a credit line to the data. 